\title{
PERENCANAAN DAN ANALISIS KELAYAKAN INVESTASI PROYEK PEMASANGAN KAPASITOR BANK PADA INSTALASI PEMANFAATAN ENERGI LISTRIK
}

\author{
Epiwardi, Ruwahyoto, Heri sungkowo \\ Jurusan Teknik Elektro, Politeknik Negeri Malang \\ e-mail: epiwardi@yahoo.co.id \\ (Artikel diterima: Oktober 2019, direvisi: September 2019, diterima untuk terbit: Januari 2020)
}

\begin{abstract}
Abstrak - The low power factor in the electricity installation of Sumber Wendit 3 water pumping stations causes a bill of excess reactive energy usage or kVARh, so that the cost of using electricity becomes higher. The excess use of reactive energy can be compensated by additional investment in installing capacitor banks in the main distribution panel (MDP) Sumber Wendit 3 water pump station. Based on the data and problems, it is planned to install capacitor banks that meet the standards with a target of 0.90 and 0.95 lagging. From the results of the planning, we need $150 \mathrm{kVAR}$ and $250 \mathrm{kVAR}$ capacitors, with an investment value of Rp. 94,983,790 and - Rp. 120,781,210. After an investment feasibility test using the Payback Period (PP) method, it is known that for a $150 \mathrm{kVAR}$ bank capacitors, the investment return is technically 2.88 months and economically is 4.01 and 3.17 months. For 250 kVAR bank capacitors, the return on investment is technically 3.66 months and economically 5.1 and 4.03 months. When compared with the economic life of the investment is 10 years, the investment of the bank capacitor installation project is very profitable and feasible to carry out
\end{abstract}

Kata kunci: Power Factor, reactive power, Bank Capacitors, investment

\section{Pendahuluan}

Rendahnya faktor daya pada instalasi pemanfaatan energy listrik stasiun pompa air Sumber Wendit 3, menyebabkan Perusahaan Daerah Air Minum (PDAM) Kota Malang harus membayar denda kelebihan pemakaian energi reaktif atau $\mathrm{kVARh}$, sehingga biaya pemakaian energi listrik menjadi lebih tinggi. Kelebihan pemakaian energi reaktif tersebut dapat dikompensasi dengan tambahan investasi untuk pemasangan kapasitor bank.

Pada penelitian ini akan menganalisa tentang alternatif perencanaan kapasitor bank, yang ditinjau secara teknis dan ekonomis. Berdasarkan hasil perencanaan, dapat dihitung kebutuhan tambahan investasi untuk pemasangan kapasitor bank. Selanjutnya akan dilakukan analisa dan uji kelayakan investasi untuk mengetahui apakah secara bisnis investasi tersebut layak dan menguntungkan.

\section{Tinjauan Pustaka}

\section{A. Faktor Daya}

Jika arus dan tegangan adalah sinyal sinusoidal sempurna, maka faktor daya adalah nilai cosinus sudut $(\varphi)$ antara daya nyata dengan daya semu atau disebut juga dengan $\cos \varphi$. Nilai faktor daya yang baik adalah mendekati satu, sedangkan nilai faktor daya rendah menunjukkan kondisi sebaliknya. (Schneider electric,2008:L3)

$$
\begin{aligned}
\mathrm{PF} & =\operatorname{Cos} \varphi \quad \operatorname{Cos} \varphi=\frac{P}{S} \\
\mathrm{P} & =\text { Daya nyata }(\mathrm{kW}) \\
\mathrm{S} & =\text { Daya Semu }(\mathrm{kVA})
\end{aligned}
$$

Ada tiga jenis daya listrik, yaitu:

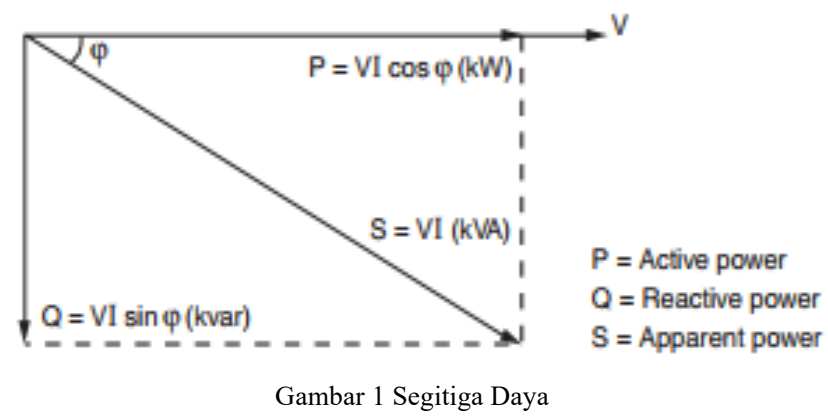

\section{B. Penyebab Faktor daya yang rendah}

Faktor daya yang rendah dihasilkan oleh peralatan seperti motor induksi, terutama pada beban-beban rendah, dan unit-unit balast dari lampu pelepasan yang memerlukan arus magnetisasi reaktif untuk gerakannya. Alat-alat las busur listrik.

\section{Perbaikan Faktor Daya}

Perbaikan faktor daya umumnya adalah penambahan komponen sebagai pembangkit daya reaktif (Reactif power generation) yang memungkinkan untuk mensuplai kebutuhan kVAR pada beban-beban induktif. Didalam rangkaian arus bolak balik, arus dapat bersifat mendahului (leading), sefasa atau terlambat (lagging) terhadap tegangan, tergantung dari macam bebannya. Dengan adanya beban resistif, induktif dan kapasitif pada sumber arus bolak-balik (AC) maka dapat dibedakan ada 3 daya yaitu daya nyata $(\mathrm{P})$, daya reaktif $(\mathrm{Q})$ dan daya semu (S).

Untuk merencanakan suatu sistem dalam memperbaiki faktor daya, dapat dipergunakan suatu konsep yaitu kompensator ideal, dimana sistem ini dapat dihubungkan pada titik penyambungan secara paralel dengan beban dan memenuhi 3 fungsi utama, yaitu memperbaiki faktor daya mendekati nilai 1 (unity power factor), mengurangi atau mengeliminasi regulasi tegangan dan menyeimbangkan arus beban dan tegangan fasa. Untuk memenuhi kebutuhan daya 
reaktif yang efektif dan efisien, maka perlu dilakukan pemilihan sumber daya reaktif untuk perbaikan faktor daya.

\section{Kapasitor Bank}

Kapasitor Bank adalah rangkaian yang terdiri dari beberapa unit kapasitor. Kapasitas unit kapasitor menyatakan besar daya reaktif nominal yang dihasilkan pada tegangan dan frekuensi nominal, dinyatakan dalam satuan dasar VAr. Praktisnya, unit kapasitor diproduksi dalam kapasitas tertentu dan bersifat diskrit .(Teguh Prayudi dan Wiharja, 2014)

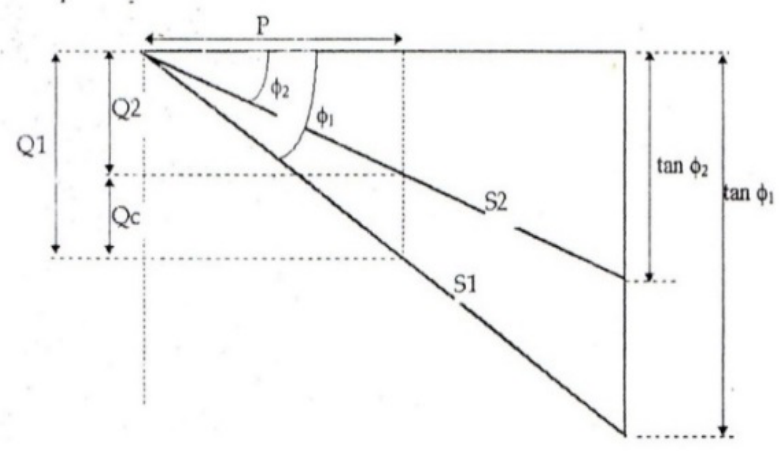

Gambar 2. Diagram fasor daya

Vektor penjumlahan antara daya aktif dan daya reaktif, sedangkan pada gambar 2, adalah gambar perbaikan faktor daya dengan kompensator daya reaktif (kapasitor) yang dibutuhkan untuk memperbaiki faktor daya beban adalah sebagai berikut:

Daya reaktif pada faktor daya awal

$$
\mathrm{Q} 1=\mathrm{P} 1 \times \tan 1 \theta
$$

Daya reaktif pada faktor daya yang diperbaiki

dimana $\mathrm{P} 2=\mathrm{P} 1=$ konstan

$$
\mathrm{Q} 2=\mathrm{P} 2 \times \tan 2 \theta \text {; }
$$

Sehingga rating kapasitor yang diperlukan untuk memperbaiki faktor daya adalah,

Daya reaktif $(\Delta Q)=\mathrm{Q} 1-\mathrm{Q} 2$

$$
=\mathrm{P} \times(\tan 1 \theta-\tan 2 \theta)
$$

\section{E. Prinsip Kerja Kapasitor}

Prinsip Kerja Kapasitor ada dua macam yaitu (Schneider electric,2008:327):

\section{Fixed Type}

Adalah dengan memberikan sebuah beban kapasitif yang tetap ataupun berubah-rubah pada beban. Biasanya digunakan pada beban langsung seperti pada motor induksi. Pada tipe ini harus dipertimbangkan adalah pada saat pemasangan kapasitor bank tanpa beban.

\section{Automatic Type}

Adalah memberikan beban kapasitif yang bervariasi sesuai dengan kebutuhan kapasitor bank yang terpasang. Pada tipe ini jenis panel dilengkapi dengan sebuah Power Factor Controller (PFC) sebagai pengaman. PFC akan menjaga cos phi pada jaringan listrik yang sesuai dengan target yang ditentukan. Apabila pada tipe ini terjadi perubahan beban, maka PFC secara otamatis akan memperbaiki cos phi.

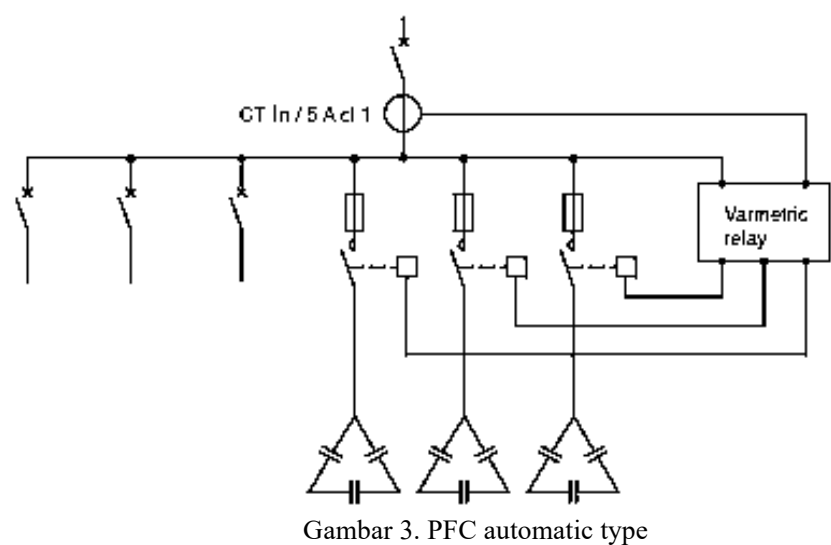

\section{F. Lokasi Pemasangan Instalasi Kapasitor Bank}

Cara pemasangan instalasi kapasitor bank dapat dibagi menjadi 3 bagian yaitu: global compensation, individual compensation dan group compensation.

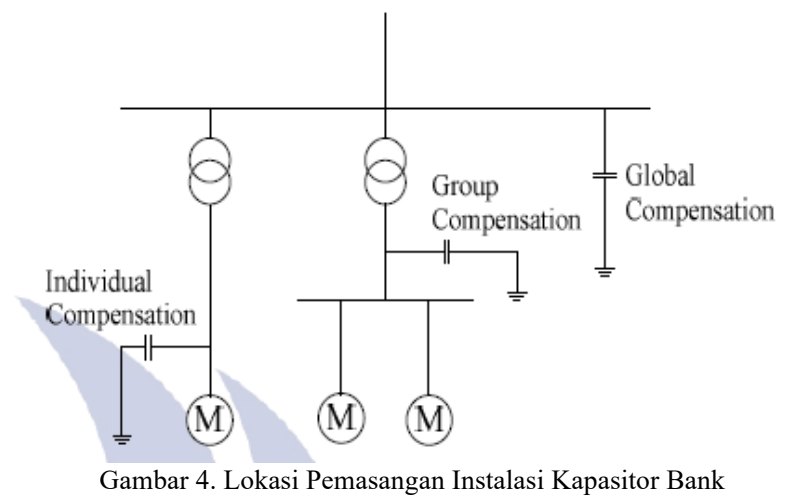

\section{G. Pengertian dan bentuk investasi}

Kebijaksanaan investasi jangka panjang, menurut Gitosudarmo dan Basri (2002:133) dikatakan sebagai persoalan capital budgeting. Investasi berarti pula sebagai pengeluaran saat ini dimana hasil yang diharapkan dari pengeluaran itu baru akan diterima lebih dari satu tahun mendatang, jadi menyangkut jangka panjang. Dalam hal ini pengeluaran untuk aktiva yang memiliki usia kurang dari satu tahun diklasifikasikan/digolongkan ke dalam kebijaksanaan investasi atau sering pula dikatakan sebagai persoalan capitas budgeting.

Salah satu tugas utama di dalam persoalan kebijaksanaan investasi adalah mengadakan estimasi terhadap pengeluaran dan penerimaan uang yang akan diterima dari investasi tersebut pada waktu yang akan datang. Perhitungan terhadap nilai investasi dengan nilai dari penerimaan uang dimasa depan (future cash flow) ini akan dapat dipakai sebagai pedoman kebijaksanaan investasi tersebut. Hasil perbandingan itu akan merupakan informasi bagi kita untuk menilai apakah ekonomis tidaknya suatu rencana investasi tertentu. Penilaian dengan perbandingan kedua hal tersebut amat penting karena perusahaan menginvestasikan uang sekarang dengan harapan dapat memperoleh uang yang lebih besar jumlahnya dimasa depan. Dengan penerimaan uang itu perusahaan dapat menginvestasikan kembali untuk rencana setiap investasi, diperlukan informasi tentang estimasi penerimaan kas dimasa depan. 


\section{H. Metode Penilaian Kelayakan Investasi}

Dalam penilaian menguntungkan tidaknya suatu investasi yang akan dipakai untuk mengambil keputusan investasi ada beberapa kriteria yang digunakan. Pada dasarnya kriteria penilaian investasi menurut Gitosudarmo dan Basri (2002:139) dapat digolongkan menjadi dua golongan adalah :

1. Kriteria investasi yang mendasarkan pada konsep keuntungan/income adalah Avarage Rate of Return (ARR)/Accounting Rate of Return (ARR).

2. Kriteria investasi yang mendasarkan pada konsep cash flow. Sedangkan kriteria investasi yang mendasarkan pada konsep cash flow dapat dirinci :

a) Konsep cash flow yang tidak memperhatikan nilai waktu dan uang atau faktor diskonto (nondiscount cash flow) yaitu metode pay back periode.

b) Konsep cash flow yang memperhatikan nilai waktu dan uang atau faktor diskonto (discounted cash flow), antara lain :

1) Nilai sekarang bersih/netto atau Net Present Value (NPV)

2) Indek keuntungan/Profitability Indek (PI)

3) Internal Rate of Return (IRR)

\section{Metode Penelitian}

Ringkasan dari rencana pelaksanaan kegiatan penelitian mulai dari tahap persian, pengambilan dan pengolahan data dapat diuraikan pada Gambar 5.

\section{Hasil Dan Pembahasan}

\section{A. Sistem Kelistrikan PDAM Sumber Wendit}

PDAM Sumber Wendit memiliki sumber utama dari PT. PLN dengan kapasitas tersambung $1730 \mathrm{kVA}$ yang didistribusikan melalui 2 buah trafo dengan kapasitas 1250 $\mathrm{kVA}$, termasuk pelanggan golongan I-3 (TM/TM/TR) yaitu pelanggan tegangan menengah (TM) $20 \mathrm{kV}$, pengukuran pada sisi tegangan menengah (TM) $20 \mathrm{kV}$ dan penggunaan pada sisi tegangan rendah (TR) $380 \mathrm{~V}$.

Pada saat beban puncak, semua pompa beroprasi dan apabila kebutuhan air tidak terlalu tinggi ada beberapa pompa yang di matikan. Sumber Wendit 1 mempunyai 4 motor pompa dan Sumber Wendit 3 mempunyai 6 motor pompa namun tidak semua pompa aktif, kecuali saat beban puncak atau kebutuhan penyuplaian air tinggi.

\section{B. Perencanaan Kapasitor Bank}

Pengukuran parameter pemakaian energi listrik dilakukan pada panel distribusi utama (MDP) dalam waktu 24 jam, dengan perekaman per 5 menit. Data hasil pengukuran kemudian dirata-rata per jam dan per hari, seperti pada Tabel 1.

Berdasarkan hasil analisa data diketahui kebutuhan daya rata-rata selama 24 jam adalah sebesar $637,48 \mathrm{~kW}$, dengan faktor daya (cosphi) 0,82. Data ini merupakan parameter awal kualitas daya untuk menentukan kebutuhan kapasitor bank untuk targe cosphi 0,9 dan 0,95 tertinggal (lagging).

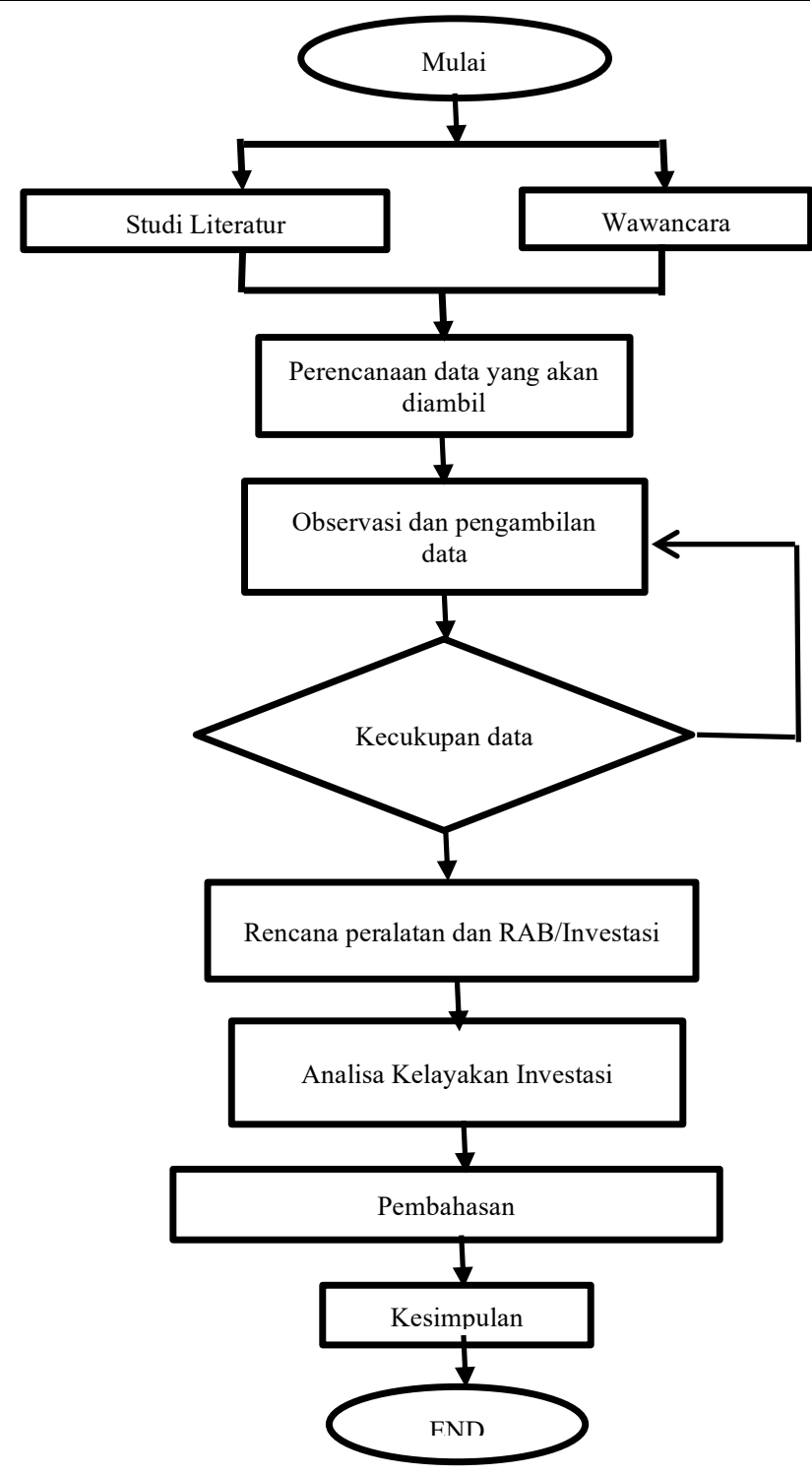

Gambar 5. Diagram Alir Penelitian

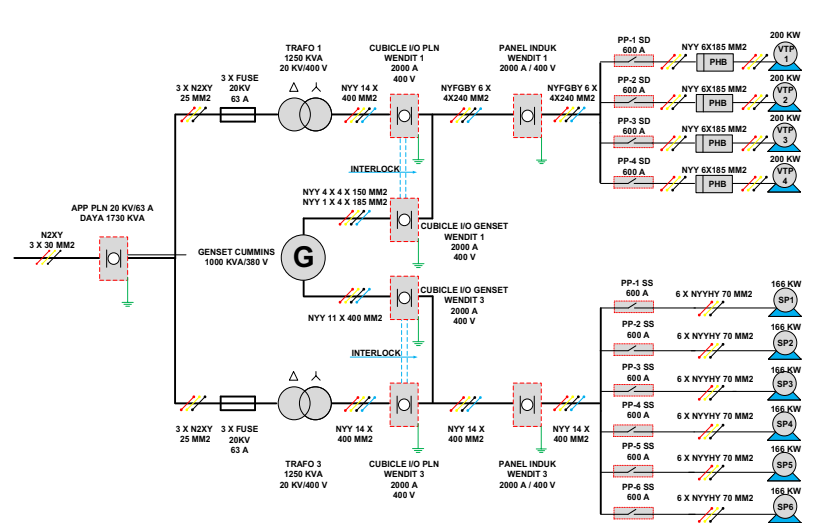

Gambar 6 Single Line Diagram Power System 
Tabel 1. Hasil Analisa Data Pengukuran

\begin{tabular}{|c|c|c|c|c|}
\hline \multirow{2}{*}{ WAKTU } & $\begin{array}{l}\text { KVAR } \\
\text { Total }\end{array}$ & KVA Total & KW Total & \multirow{2}{*}{$\begin{array}{c}\text { PF } \\
\text { Total }\end{array}$} \\
\cline { 2 - 4 } & KVAR & KVA & KW & \\
\hline $09: 02-57$ & 414.6 & 741.6 & 612.3 & 0.83 \\
\hline $10: 02-57$ & 419.0 & 744.3 & 613.1 & 0.82 \\
\hline $11: 02-57$ & 419.0 & 743.4 & 611.6 & 0.82 \\
\hline $12: 02-57$ & 423.5 & 746.9 & 612.9 & 0.82 \\
\hline $13: 02-57$ & 424.8 & 746.8 & 612.1 & 0.82 \\
\hline $14: 02-57$ & 428.4 & 750.4 & 614.0 & 0.82 \\
\hline $15: 02-57$ & 508.2 & 896.8 & 736.7 & 0.82 \\
\hline $16: 02-57$ & 521.1 & 927.2 & 764.5 & 0.83 \\
\hline $17: 02-57$ & 512.0 & 923.1 & 765.6 & 0.83 \\
\hline $18: 02-57$ & 424.8 & 761.9 & 629.6 & 0.83 \\
\hline $19: 02-57$ & 415.9 & 740.8 & 610.7 & 0.82 \\
\hline $20: 02-57$ & 422.5 & 746.4 & 613.4 & 0.82 \\
\hline $21: 02-57$ & 422.8 & 746.5 & 613.0 & 0.82 \\
\hline $22: 02-57$ & 430.1 & 749.6 & 611.6 & 0.82 \\
\hline $23: 02-57$ & 423.6 & 747.5 & 613.7 & 0.82 \\
\hline $00: 02-57$ & 425.6 & 751.1 & 616.6 & 0.82 \\
\hline $01: 02-57$ & 427.7 & 749.3 & 612.8 & 0.82 \\
\hline $02: 02-57$ & 432.3 & 755.6 & 617.5 & 0.82 \\
\hline $03: 02-57$ & 432.6 & 755.9 & 617.4 & 0.82 \\
\hline $04: 02-57$ & 424.5 & 751.5 & 617.7 & 0.82 \\
\hline $05: 02-57$ & 405.1 & 738.7 & 614.8 & 0.82 \\
\hline $06: 02-57$ & 416.3 & 745.1 & 615.3 & 0.83 \\
\hline $07: 02-57$ & 415.5 & 743.5 & 614.2 & 0.83 \\
\hline $08: 02-57$ & 482.7 & 884.6 & 738.3 & 0.84 \\
\hline \multirow{2}{*}{ RATA- } & $\mathrm{kVAR}$ Total & $\mathrm{kVA} \mathrm{Total}$ & $\mathrm{kW} \mathrm{Total}$ & \multirow{2}{*}{ PF } \\
\cline { 2 - 4 } RATA & KVAR & $\mathrm{kVA}$ & $\mathrm{kW}$ & \multirow{2}{*}{ Total } \\
\cline { 1 - 4 } & $\mathrm{RMS}$ & $\mathrm{RMS}$ & $\mathrm{RMS}$ & \\
\hline NILAI & 436.37 & 774.52 & 637.48 & 0.82 \\
\hline & & & & \\
\hline
\end{tabular}

\section{Kebutuhan kapasitor bank}

Target yang akan dicapai adalah melebihi batas minimal standart SPLN $\geq 0,85$, maka perlu menambahkan beban yang bersifat kapasitif ke dalam sistem tersebut. Berikut adalah perhitungan untuk perbaikan PF awal 0,82 menjadi 0, dan 0,95 lagging. :

Untuk cosphi target 0,90 lagging :

Qc $\quad=\mathrm{P}(\tan \varphi 1-\tan \varphi 2)$

$$
\begin{aligned}
& =637,48\left(\tan \left(\cos ^{-1} 0,82\right)-\tan \left(\cos ^{-1} 0,90\right)\right) \\
& =637,48(0,698-0,484) \\
& =136,420 \mathrm{kVAR}
\end{aligned}
$$

Untuk cos phi 0,95 lagging :

Qc $\quad=\mathrm{P}(\tan \varphi 1-\tan \varphi 2)$

$=637,48\left(\tan \left(\cos ^{-1} 0,82\right)-\tan \left(\cos ^{-1} 0,9\right)\right)$

$=637,48(0,698-0,329)$

$=235,230 \mathrm{kVAR}$

Berdasarkan data perencanaan diatas, dapat digambarkan instalasi dan control kapasitor bank seperti terlihat pada gambar berikut.

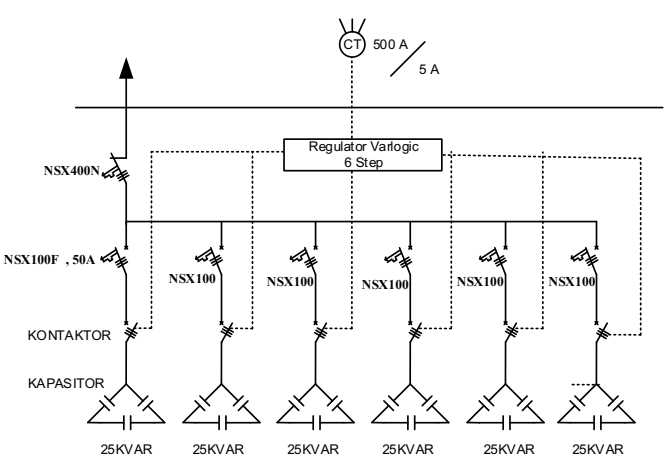

Gambar 7. Instalasi dan Kontrol Kapasitor 150 KVAR

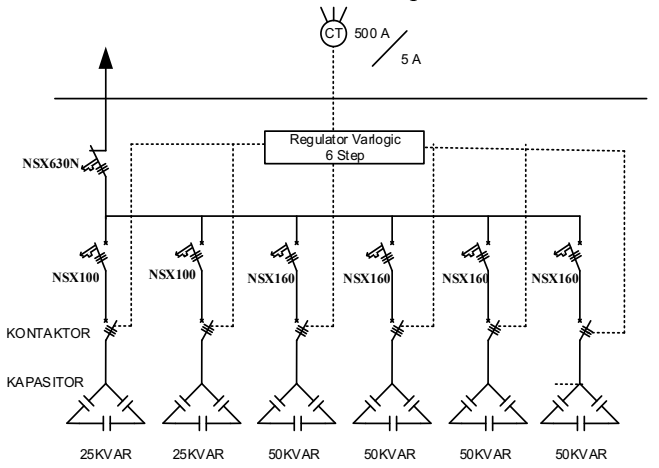

Gambar 8. Instalasi dan Kontrol Kapasitor 250 KVAR

\section{Biaya Investasi Pemasangan Kapasitor}

Berdasarkan perencanaan didapatkan biaya investasi pemasangan kapasitor bank $150 \mathrm{kVAR}$ adalah sebesar Rp. 94.983.790,- dan 250 kVAR adalah Rp. 120.781.210,-

\section{E. Biaya pemakaian kelebihan $\mathrm{kVARh}$}

Biaya tagihan kelebihan $\mathrm{kVARh}$ menjadi suatu keuntungan, yang dapat membiayai kebutuhan pemasangan kapasitor bank, dengan kata lain merupakan biaya untuk pengembalian investasi. Biaya kelebihan pemakaian kVARh secara teknis dapat dihitung dari data pengukuran dan secara ekonomis dapat diperoleh dari biaya tagihan denda kelebihan $\mathrm{kVARh}$. Berikut ini akan dianalisa tentang biaya kelebihan pemakaian kVARh::

Daya Aktif $(\mathrm{Pt})=637,48 \mathrm{~kW}$

Daya Reaktif $(\mathrm{Qt})=436,37 \mathrm{kVAR}$

Standar Q $(\mathrm{Qs}) \quad=62 \% \mathrm{x} \mathrm{Pt}=395,24 \mathrm{kVAR}$

Kelebihan Q $(\mathrm{Qk})=\mathrm{Qt}-\mathrm{Qs}=41,13 \mathrm{kVAR}$

Kelebihan $\mathrm{kVARh}=\mathrm{Qk} \times$ waktu per bulan

$$
=41,13 \times 24 \times 30=29.614 \mathrm{kVARh}
$$

Tarif per kVARh tahun $2019=$ Rp. 1114.74

Biaya Kelebihan kVARh Teknis $=29.614$ x Rp. 1114,74

$$
=\text { Rp. 33.000.000,- }
$$

Untuk biaya kelebihan pemakaian $\mathrm{kVARh}$ dari data tagihan dapat dilihat pada tabel 3.3, yaitu terdiri dari biaya rata-rata dan biaya tertinggi, diantara bulah Juli 2018 sampai dengan Januari 2019.

Biaya kelebihan kVARh Rata-rata = Rp. 23.666.727,- 
Biaya kelebihan kVARh maksimum= Rp. 29.957.523,-

\section{F. Analisis Kelayakan Investasi}

Untuk dapat menilai kelayakan suatu investasi pada usulan proyek perbaikan factor daya secara ekonomis, maka analisis keuangan sangat diperlukan agar dapat diambil pertimbangan untung atau ruginya suatu investasi. Analisis keuangan yang digunakan dalam penelitian ini adalah metode "Payback Period".

\section{G. Penetapan proyek}

Proyek ini akan mempunyai umur ekonomis jangka panjang, dan akan selalu memberikan kontribusi terus menerus. Berdasarkan spesifikasi matrial, maka ditetapkan “umur ekonomis proyek" selama 10 tahun.

Dalam analisis keuangan proyek, kontribusi kVARh merupakan " keuntungan bersih " dalam bentuk uang, yang nilainya dapat dilihat lansung pada tagihan pemakaian listrik bulanan. Didalam penelitian ini, “keuntungan” yang diperoleh dari proyek pemasangan kapasitor ini dianggap tetap dan keuntungan ini disebut juga sebagai "tambahan cash flow". Investasi pada proyek ini adalah berupa biaya matrial dan pemasangan kapasitor. Dalam analisis keuangan, investasi ini disebut dengan istilah "tambahan investasi".

\section{H. Data proyek pemasangan kapas}

\section{I. itor bank}

Tabel 2. Data Usulan Proyek Pemasangan Kapasitor Bank

\begin{tabular}{|c|l|r|r|}
\hline $\begin{array}{c}\mathrm{N} \\
\text { o. }\end{array}$ & \multicolumn{1}{|c|}{ URAIAN } & QC 150 kVAR & QC 250 kVAR \\
\hline \hline 1 & Tambahan investasi & $94,983,790$ & $120,781,210$ \\
\hline 2 & Umur investasi (Tahun) & 33.000 .000 & 33.000 .000 \\
\hline 3 & $\begin{array}{l}\text { Keuntungan setelah pajak } \\
\text { (EAT) Teknis }\end{array}$ & 23.666 .727 & 23.666 .727 \\
\hline 4 & $\begin{array}{l}\text { Keuntungan setelah pajak } \\
\text { (EAT) ekonomis Rata2 }\end{array}$ & 29.957 .523 & 29.957 .523 \\
\hline 5 & $\begin{array}{l}\text { Keuntungan setelah pajak } \\
\text { (EAT) ekonomis maks }\end{array}$ & & \multicolumn{2}{|c}{} \\
\hline
\end{tabular}

\section{J. Analisis metode payback period (PP)}

Tabel 3. Analisis Payback Period Teknis

\begin{tabular}{|l|r|r|}
\hline \multicolumn{1}{|c|}{ Uraian } & QC 150 kVAR & \multicolumn{1}{c|}{ QC 250 kVAR } \\
\hline \hline \multicolumn{1}{|c|}{ Investasi } & 94.983 .790 & 120.781 .210 \\
\hline Cash flow Bulan I & 33.000 .000 & 33.000 .000 \\
\hline Saldo & 61.938 .790 & 87.781 .210 \\
\hline Cash flow Bulan 2 & 33.000 .000 & 33.000 .000 \\
\hline Saldo & 28.938 .790 & 54.781 .210 \\
\hline Cash flow Bulan 3 & 33.000 .000 & 33.000 .000 \\
\hline Saldo & $(4.061 .210)$ & 21.781 .210 \\
\hline Cash flow Bulan 4 & & 33.000 .000 \\
\hline Saldo & & $(11.218 .790)$ \\
\hline
\end{tabular}

Payback period Kapasitor $150 \mathrm{kVAR}=2,88$ Bulan

Payback period Kapasitor $250 \mathrm{kVAR}=3,66$ Bulan
Tabel 4. Analisis Payback Period Ekonomis Rata-rata

\begin{tabular}{|l|r|r|}
\hline \multicolumn{1}{|c|}{ Uraian } & QC 150 kVAR & QC 250 kVAR \\
\hline \hline \multicolumn{1}{|c|}{ Investasi } & 94.983 .790 & 120.781 .210 \\
\hline Cash flow Bulan I & 23.666 .727 & 23.666 .727 \\
\hline Saldo & 71.317 .063 & 97.114 .483 \\
\hline Cash flow Bulan 2 & 23.666 .727 & 23.666 .727 \\
\hline Saldo & 47.650 .336 & 73.447 .756 \\
\hline Cash flow Bulan 3 & 23.666 .727 & 23.666 .727 \\
\hline Saldo & 23.983 .609 & 49.781 .029 \\
\hline Cash flow Bulan 4 & 23.666 .727 & 23.666 .727 \\
\hline Saldo & 316.882 & 26.114 .302 \\
\hline Cash flow Bulan 5 & & 23.666 .727 \\
\hline Saldo & & 2.447 .575 \\
\hline
\end{tabular}

Payback period Kapasitor $150 \mathrm{kVAR}=4,01$ Bulan

Payback period Kapasitor $250 \mathrm{KVAR}=5,1$ Bulan

Tabel 5.Analisis Payback Period Ekonomis Maksimum

\begin{tabular}{|l|r|c|}
\hline \multicolumn{1}{|c|}{ Uraian } & QC 150 kVAR & QC 250 kVAR \\
\hline \hline \multicolumn{1}{|c|}{ Investasi } & 94.983 .790 & 120.781 .210 \\
\hline Cash flow Bulan I & 29.957 .523 & 29.957 .523 \\
\hline Saldo & 65.026 .267 & 90.823 .687 \\
\hline Cash flow Bulan 2 & 29.957 .523 & 29.957 .523 \\
\hline Saldo & 35.068 .744 & 60.866 .164 \\
\hline Cash flow Bulan 3 & 29.957 .523 & 29.957 .523 \\
\hline Saldo & 5.111 .221 & 30.908 .641 \\
\hline Cash flow Bulan 4 & & 29.957 .523 \\
\hline Saldo & & 951.118 \\
\hline
\end{tabular}

Payback period Kapasitor $150 \mathrm{kVAR}=3,17$ Bulan

Payback period Kapasitor $250 \mathrm{kVAR}=4,03$ Bulan

\section{K. Pembahasan hasil analisis teknis}

Analisis teknis bertujuan untuk mengetahui nilai kapasitas kapasitor bank yang dibutuhkan untuk memperbaiki kualitas daya pada instalasi pemanfaatan energi listrik stasiun pompa air, sehingga kelebihan pemakaian $\mathrm{kVARh}$ dapat dikompensasi. Dari hasil analisis diperoleh besarnya kapastas kapasitor bank untuk target Cosphi 0,9 adalah sebesar $150 \mathrm{kVAR}$ dan untuk target cosphi 0,95 sebesar 250 kVAR. Kedua kapasitas kapasitor bank tersebut, dapat menghilangkan kelebihan pemakaian $\mathrm{kVARh}$, tetapi secara teknis kapasitas $250 \mathrm{kVAR}$ akan lebih baik.

\section{Pembahasan hasil analisis kelayakan investasi}

Perencanaan instalasi dan control kapasitor bank, untuk mengetahui kebutuhan peralatan dan besarnya biaya investasi. Besarnya nilai investasi untuk kapasitor bank 150 kVAR adalah sebesar Rp. 94.983.790,- dan untuk kapasitor 250 kVAR adalah sebesar Rp. 120.781.210,- Nilai Investasi ini sudah termasuk PPN sebesar $10 \%$.

Analisis payback period (PP) bertujuan untuk mengukur tingkat priode pengembalian investasi yang ditanamkan dengan sumber yang berasal dari aliran kas (cash flow). Hasil analisis payback period (PP) pada proyek pemasangan kapasitor bank diketahui tingkat pengembalian investasi untuk kapasitor bank150 kVAR secara teknis adalah 2,88 bulan dan secara ekonomis adalah 4,01 dan 3,17 bulan. Untuk kapasitor bank $250 \mathrm{kVAR}$ secara teknis adalah 3,66 bulan dan secara ekonomis adalah 5,1 dan 4,03 bulan. Jika umur ekonomis proyek adalah 10 tahun, maka keputusan 
investasi adalah sangat menguntungkan dan layak untuk diterima/dilaksanakan.

\section{KeSIMPUlan Dan SARAN}

\section{A. Kesimpulan}

Berdasarkan hasil analisis dan pembahasan pada penelitian ini, dapat disimpulkan bahwa investasi pada proyek pemasangan kapasitor bank pada instalasi pemanfaatan energi listrik stasiun pompa air Wendit 3 PDAM Kota Malang adalah menguntungkan dan layak untuk diterima/dilaksanakan, dengan hasil sebagai berikut :

1. Untuk memperbaiki kualitas daya dari faktor daya ratarata awal 0,82, menjadi target factor daya 0,9 , diperoleh kapasitas kapasitor bank $150 \mathrm{kVAR}$, dan untuk target faktor daya 0,95 adalah $250 \mathrm{kVAR}$.

2. Nilai investasi proyek pemasangan kapasitor bank 150 kVAR adalah Rp. 94.983.790,- dan untuk kapasitor bank 250 kVAR adalah Rp. 120.781.210,-

3. Hasil analisis uji kelayakan investasi dengan metode Payback Period (PP ) diperoleh pengembalian investasi untuk kapasitor $150 \mathrm{kVAR}$ secara teknis adalah 2,88 bulan dan secara ekonomis 4,01 dan 3,17 bulan. Untuk kapasitor $250 \mathrm{kVAR}$ secara teknis adalah 3,66 bulan dan secara ekonomis 5,1 dan 4,03 bulan. Untuk umur efektif investasi 10 tahun, maka investasi ini sangat menguntungkan dan layak untuk dilaksanakan.

\section{B. Saran}

Sehubungan dengan hasil analisis dan pembahasan pada penelitian ini, sebaiknya pihak manajemen dan pengelola PDAM Kota Malang, khususnya stasiun pompa Wendir 3, menerima dan melaksanakan proyek pemasangan kapasitor bank pada instalasi pemaanfaatan energy listrik, dengan kapasitas $250 \mathrm{kVAR}$, untuk perbaikan kualitas daya/faktor daya yang rendah dan menghilangkan denda kelebihan pemakaian daya reaktif/kVARh.

\section{DAfTaR Pustaka}

[1] Anonim. (2019). Koreksi Faktor Daya. In Daftar Harga 2019 PT Schneider Indonesia (ch. 9). Schneider Electric.

[2] Anonim. (2010). Reactive Energy Management LV Components. In Schneider Meher Power Capacitors Catalouge. Schneider Electric.

[3] Gitosudarmo, Indriyo dan Basri, 2002, Manajemen Keuangan, Edisi 4, cetakan pertama, Yogyakarta, BPFE- Yogyakarta.

[4] PLN (Persero), PT., 2019, Tarif Dasar Listrik 2019, TDL 2019, PT. PLN (Persero), Jakarta.

[5] Syamsuddin, Lukman. 1985. Manajemen Keuangan Perusahaan, Edisi Baru-9, PT. Raja Grafindo Persada, Jakarta.

[6] Suratman, Drs. M.Si.2001. Studi Kelayakan Proyek, Teknik dan Prosedur Penyusunan Laporan, Edisi Pertama, Cetakan Pertama, Penerbit: JJ Learning, Yogyakarta.

[7] Yogiyanto H.M., Prof. Dr. MBD., Akt, 2004, Metodologi Penelitian Bisnis, Edisi 2004/2005, BPFE, Yogyakarta. 